DOI: http://dx.doi.org/10.18778/8142-717-3.01

\author{
MACIEJ DAWCZYK \\ (UNIWERSYTET ŁÓDZKI)
}

\title{
NARSES I LONGOBARDOWIE
}

\begin{abstract}
Streszczenie. Narses po raz pierwszy zetknął się z Longobardami najprawdopodobniej, kiedy walczyli pod jego komendą w trakcie kampanii przeciw Ostrogotom z 552 r. Choć okazali się dzielnymi żołnierzami, to potem dopuścili się licznych ekscesów wobec ludności cywilnej i zostali wydaleni do swojej ojczystej Panonii. Według części źródeł (np. Izydor z Sewilli, Liber pontificalis) Narses zaprosił Longobardów do Italii w 568, chcąc zemścić się na cesarzowej Zofii. Tej wersji wydarzeń nie potwierdza jednak większość najwcześniejszych źródeł (Mariusz z Avenches, Grzegorz z Tours, źródła bizantyńskie). Narracji o konszachtach wodza z Longobardami nie można jednak całkowicie odrzucić, ze względu na fakt, że znaleźć ją można w wielu źródłach niezależnych od siebie i mimo wszystko stosunkowo wiarygodnych. W nawiązaniu do hipotezy Neila Christiego można zaproponować jej rozwinięcie, które godziłoby sprzeczne przekazy i rozwiązywało problem w postaci sprzeczności ewentualnego celowego osiedlania Longobardów w Italii z niechętną barbarzyńcom polityką prowadzoną w tym czasie przez cesarstwo. Być może Narses nawiązał kontakty z Longobardami w dobrej wierze, lecz zrobił to wbrew woli pary cesarskiej, co poskutkowało jego odwołaniem. Możliwe, próba osiedlenia ludu jako sojuszników, nie była skutkiem zaproszenia, a jedynie nieudaną próbą uporządkowania stanu faktycznego, spowodowanego ich samowolnym wkroczeniem na terytorium półwyspu.
\end{abstract}

Słowa kluczowe: Bizancjum, Italia, Longobardowie, Narses, średniowiecze.

\section{Wprowadzenie}

$\mathrm{N}$ arses był jednym z najbardziej znanych współpracowników cesarza Justyniana I. Pochodzący z Armenii eunuch zrobił zawrotną karierę w szeregach bizantyńskiej machiny państwowej i odegrał kluczową rolę w realizowanym przez cesarza programie rekonkwisty zachodniej części imperium z rąk barbarzyńców. Jego zwycięstwo nad Ostrogotami w bitwie pod Busta Gallorum w 552 r. ostatecznie załamało ich italskie królestwo i umożliwiło odzyskanie przez Bizancjum pełnej kontroli nad Półwyspem Apenińskim. Następnie wódz zajmował się zwalczaniem niedobitków 
ostrogockich i frankijskich oraz administrowaniem, z ramienia cesarza, świeżo odzyskaną Italią, aż do najazdu longobardzkiego w 568 r., który zniweczył długoletnie wysiłki Bizancjum i sprawił, że większa część półwyspu wpadła ponownie w ręce ludu germańskiego ${ }^{1}$.

Źródła odnotowują tylko dwa epizody, w których działania Narsesa i Longobardów miały spleść się ze sobą - walkę ludu pod komendą wodza w kampanii italskiej przeciw Ostrogotom w 552 r., a następnie rzekomy udział Narsesa w sprowadzeniu Longobardów do Italii w 568 r. Pierwszy z nich znany jest tylko dzięki narracji Prokopiusza z Cezarei i sam w sobie nie mógłby stanowić pola dla odrębnych badań. Drugi natomiast, choć traktowany zwykle przez autorów źródeł bardzo skrótowo, stanowi przedmiot niemałych kontrowersji, ze względu na spore rozbieżności między przekazami go dotyczącymi. Fakt ten oraz różnorodność punktów widzenia, pojawiająca się $w$ pracach poruszających to zagadnienie, sprawiają, że temat wart jest ciągle analizy.

\section{Longobardowie pod Busta Gallorum}

Longobardowie najpóźniej od II poł. lat 30. VI w. byli sojusznikami Bizancjum, wykorzystywanymi jako przeciwwaga zarówno przeciw Gotom, jak i Gepidom. W tym czasie, zajęli też etapami (pierwszy w latach 20., drugi w latach 40. VI w.) obszar Panonii, pozostającej poza kontrolą Bizancjum najpewniej już od czasów Attyli. W jej północnej części osiedlili się samowolnie, natomiast ich bytność w części południowej zalegalizował oficjalnie cesarz Justynian².

Prokopiusz z Cezarei odnotował w swoich Wojnach Gockich, że posiłki longobardzkie znalazły się w składzie wojsk bizantyńskich, walczących w Italii

${ }^{1}$ Na temat działalności Narsesa na przestrzeni całego jego życia vide; np. L. Fauber, Nares. Hammer of the Goths, Gloucester-New York 1990, passim; T. Wolińska, Armeńscy wspótpracownicy Justyniana Wielkiego. Część 2. Wielka kariera eunucha Narsesa, „Przegląd Nauk Historycznych" 2005, R. 4, nr 1, s. 29-50.

2 Właściwie jedynym źródłem dostarczającym informacji na temat relacji bizantyńsko-longobardzkich w I poł. VI w. jest Historia Wojen Prokopiusza z Cezarei vide: Prokopiusz z Cezarei, Historia Wojen, tom II - Wojny z Gotami [dalej: Prokopiusz z Cezarei], wstęp i tłum. D. Brodka, Kraków 2015, VI, 8-22, VII, 10-12, 34-35, 39, VIII, 18, 25, 27; vide: P. Cesaretti, I Longobardi di Procopio, [w:] I Longobardi e la storia. Un percorsoattraverso le fonti, red. F. Lo Monaco e F. Mores, Roma 2012, s. 19-73; W. Pohl, The Empire and the Lombards: Treaties and Negotiations in the Sixth Century, [w:] Kingdoms of the Empire: The Integration of Barbarians in Late Antiquity, red. W. Pohl, Leiden 1997, s. 87-96; A. Sarantis, War and Diplomacy in Pannonia and the Northwest Balkans during the Reign of Justinian: The Gepid Threat and Imperial Responses, „Dumbarton Oaks Papers” 2009, vol. 63, s. 15-40; F.E. Wozniak, Byzantine Diplomacy and the Lombard-Gepidic Wars, „Balkan Studies” 1979, vol. 20, s. 139-152. 
pod wodzą Narsesa, obok innych barbarzyńców takich jak Hunowie czy Herulowie. Wedle bizantyńskiego autora, w odpowiedzi na mowę Narsesa, w której wódz zagrzewał swoich ludzi do walki, przekonując ich, że biją się za słuszną sprawę, ostrogocki król Totila wygłosił do swoich wojsk prowokacyjne przemówienie, w którym kwestionował lojalność i chęć walki posiłków barbarzyńskich $\mathrm{w}$ armii bizantyńskiej. Narses, chcąc zniechęcić wszystkich barbarzyńskich sojuszników do ewentualnej ucieczki, umieścił ich więc w centrum swoich wojsk i nakazał walczyć pieszo. Po zaciętej walce ostrogoci zostali pobici, a posiłki barbarzyńskie miały walczyć przy tym bardzo mężnie ${ }^{3}$.

Trudno powiedzieć, czy Totila rzeczywiście wygłosił podobną mowę, czy może jest to tylko zabieg literacki Prokopiusza. Z drugiej strony nie ma większych powodów, by kwestionować brak zaufania Narsesa do barbarzyńców. Longobardowie w rzeczywistości okazywali się już wcześniej krnąbrnymi sojusznikami, nie zawsze działającymi po myśli Bizancjum. Rację ma też zapewne Anthony Kaldellis, twierdząc, że we fragmencie tym odbija się niechęć Prokopiusza do obowiązującego modelu barbaryzacji armii bizantyńskiej, opierającej się nie na pozyskiwaniu rekruta indywidualnie, ale bazującej na kontyngentach, składających się z przedstawicieli konkretnych nacji barbarzyńskich, posiadających własną odrębną strukturę i dowództwo ${ }^{4}$.

Prokopiusz podaje zresztą, że bytność Longobardów w Italii przyniosła Narsesowi i miejscowej ludności sporo utrapienia. Po zwycięskiej kampanii zaczęli się oni bowiem bez skrępowania oddawać gwałtom i grabieżom. W tej sytuacji wódz zdecydował się przekazać im wysokie sumy pieniężne i czym prędzej, pod eskortą, odesłać do Panonii ${ }^{5}$.

Longobardowie zniknęli więc z Italii. Stosunki między nimi a Bizancjum w latach 50. i 60. VI w. ulegały stopniowemu pogorszeniu. Longobardowie zaczęli skłaniać się ku Frankom, z którymi cesarstwo łączyły wtedy złe relacje, ponieważ ci próbowali angażować się wtedy w sprawy Italii. Bizancjum zdecydowało się nawet, podczas konfliktu Longobardów z Gepidami z lat 565-567, przejściowo wspomóc tych ostatnich. Pamięć o pobycie w Italii i łupach przywiezionych stamtąd zapewne przetrwała wśród ludu i odegrała istotną rolę w podjęciu przez króla Alboina decyzji o migracji na półwysep ${ }^{6}$.

\footnotetext{
3 Prokopiusz z Cezarei, VIII, 30-32, s. 411-119.

${ }^{4}$ A. Kaldellis, Classicism, Barbarism, and Warfare: Prokopios and the Conservative Reaction to Later Roman Military Policy, „American Journal of Ancient History” 2004-2005, no. 3-4, s. 212.

${ }^{5}$ Prokopiusz z Cezarei, VIII, 33, s. 419-420.

${ }^{6}$ Na temat relacji bizantyńsko-longobardzkich w okresie między bitwą pod Busta Gallorum a wkroczeniem Longobardów do Italii vide: N. Christie, The Lombards. The Ancient Longobards, Oxford 1995, s. 58-63; F.E. Wozniak, Byzantine Diplomacy..., s. 152-158.
} 


\section{Narses a inwazja longobardzka na Italię w 568 r. Narracja źródeł}

Longobardowie w 567 r. ostatecznie rozbili zagrażających im Gepidów. Wcześniej jednak, w obliczu trudnej sytuacji, zmuszeni byli sprzymierzyć się z Awarami. To właśnie ten koczowniczy lud stał się rzeczywistym beneficjentem zniszczenia państwa Gepidów, ponieważ zagarnął zamieszkiwane przez nich terytoria i stał się poważnym zagrożeniem także dla Bizancjum. Trudno powiedzieć, czy król Alboin myślał o opuszczeniu niezbyt zasobnej Panonii już wcześniej czy skłoniła go do tego dopiero obawa przed zdominowaniem przez Awarów. W każdym razie wiosną $568 \mathrm{r}$. wyruszył do Italii wraz z konglomeratem ludów, którego trzon stanowili Longobardowie, ale zasilali go także choćby Sasi czy Hunowie ${ }^{7}$. Wydarzenie to pokryło się w czasie z odwołaniem Narsesa z Italii przez cesarza Justyna II.

Kilka bardzo wczesnych (pochodzących z ostatniej ćwierci VI w.) i dobrze poinformowanych w sprawach italskich źródeł, poruszających tematykę złożenia Narsesa ze sprawowanych przez niego w Italii obowiązków administracyjnych, nie wiąże tej kwestii z wątkiem longobardzkim, choć odnotowują fakt inwazji. Burgundzki autor Mariusz z Avenches w swojej Kronice podaje, że Narses został odwołany z Italii na polecenie cesarza, nie podając jednak przy tym żadnych szczegółów ${ }^{8}$. Jeszcze bardziej enigmatyczny jest przekaz Excerpta Sangallensia ${ }^{9}$, wspominających jedynie, że wódz znalazł się w tym okresie w Neapolu, po czym powrócił do Rzymu, nie wyjaśniając jednak przyczyn takiego postępowania. Tworzący w frankijskiej Galii kronikarz Grzegorz z Tours w Historii Franków wspomina jedynie o wyjeździe Narsesa

7 Informacji na temat przebiegu konfliktu z Gepidami i początku wyprawy do Italii dostarczają następujące źródła: Menander Protektor, Historia (The History of Menander the Guardsman), intro. and transl. R.C. Blockley, Liverpool 1985, XII, 1-6, s. 129-143; Teofilakt Simokatta, Historia (The History of Theophylact Simocatta), intro. and transl. M.M. Whitby, VI, 10 (4-18), s. 170-171; Origogentis Langobardorum, [w:] Monumenta Germaniae Historica, Scriptores rerum Langobardicarum et Italicarum, red. G. Waitz, Hannoverae 1878 [dalej: Origo], 5, s. 4-5; Paweł Diakon, Historia Longobardów (Pauli historia Langobardorum), [w:] Monumenta Germaniae Historica, Scriptores rerum Langobardicarum et Italicarum, red. G. Waitz, Hannoverae 1878 [dalej: Paweł Diakon], I, 27, s. 68-70; Historia Langobardorum codicis Gothani, [w:] Monumenta Germaniae Historica, Scriptores rerum Langobardicarum et Italicarum, red. G. Waitz, Hannoverae 1878 [dalej: Codicis Gothani], 5, s. 9.

${ }^{8}$ Mariiepiscopi Aventicensis chronica, [w:] Monumenta Germaniae Historica, Auctoresantiquissimi (11), Chronica minora saec. IV. V. VI. VII. (II), red. T. Mommsen, Berolini 1894, 568, s. 238: Hoc anno Narses [...] de ipsa Italia a supra scripto Augusto remotus est.

${ }^{9}$ Excerpta Sangallensia, [w:] Monumenta Germaniae Historica, Auctoresantiquissimi (9), Chronica minora saec. IV. V. VI. VII. (I), red. T. Mommsen, Berolini 1892, 711-714, s. 335-336: [...] de Neapolim egressus Narsis ingressus Romam et deposuit palatii eius statuam et Capitolium. 
z Italii i skarbach, które zgromadził wódz w trakcie sprawowanych przez siebie rządów ${ }^{10}$.

Żadnych informacji na temat ewentualnych konszachtów Narsesa z Longobardami nie dostarczają też autorzy bizantyńscy, ani wcześni (jak np. Menander Protektor), ani późni (jak chociażby Teofanes Wyznawca) ${ }^{11}$. 0 inwazji i potencjalnym związku wodza z nią milczy także piszący w końcu VI w. wizygocki autor Jan z Biklar w swojej Kronice, choć odnotowuje pewne szczegóły walk z Longobardami prowadzonych nieco później ${ }^{12}$.

Ciekawy przypadek stanowi późna (początek IX w.) relacja Agnellusa z Rawenny, autora Liber pontificalis ecclesiae Ravennatis. Agnellus, nieco podobnie jak Grzegorz z Tours, podaje w niej, że Narses opuścił Italię wraz z wielkimi skarbami, nie łącząc jego osoby z Longobardami, których wkroczenie odnotowuje w innym miejscu ${ }^{13}$. 0 ile wcześniej wymienione źródła nie wydają się być zależne od innych przekazów, to w przypadku dzieła Agnellusa sytuacja jest bardziej skomplikowana. Wiadomo, że korzystał często obszernie choćby z rzymskiego Liber pontificalis i Historii Longobardów Pawła Diakona. Jego przekaz, dotyczący schyłku pobytu Narsesa w Italii, jest jednak diametralnie inny. Wiadomo też, że autor Liber pontificalis ecclesiae Ravennatis znał twórczość Grzegorza z Tours, możliwe więc, że miał też do czynienia z Historiq Franków i to na jej podstawie zamieścił w swym dziele taką wzmiankę. Udowodnienie tego jest jednak trudne i całkiem możliwe, że informacje o Narsesie zaczerpnął z jakichś zaginionych dokumentów $\mathrm{z}$ raweńskiego archiwum (wykorzystywał bowiem jego zasoby w swoim dziele) lub zwyczajnie $z$ tradycji ustnej ${ }^{14}$.

${ }^{10}$ Gregorii episcopi Turonensis libri historiarum X, [w:] Monumenta Germaniae Historica, Scriptores rerum Merovingicarum (1,1), Gregorii Turonensis Opera. Teil 1: Libri historiarum X, red. B. Krusch, W. Levison, Hannoverae 1951, V, 19, s. 226: Narsisille dux Italiae [...] Italiam cum multis thesauris egressus.

11 Vide: P. Lamma, Sulla fortuna dei longobardi nella storiografia bizantina, [w:] Atti del primo Congresso Internazionale di Studi Longobardi: Spoleto, 27.-30 sett. 1951, Spoleto 1952, s. 351-361.

12 Iohannis Abbatis Biclarensis Chronica, [w:] Monumenta Germaniae Historica, Auctoresantiquissimi (11), Chronica minora saec. IV. V. VI. VII. (II), red. T. Mommsen, Berolini 1894, s. 213-219.

13 Agnelli liber pontificalis ecclesiae Ravennatis, [w:] Monumenta Germaniae Historica, Scriptores rerum Langobardicarum et Italicarum, red. G. Waitz, Hannoverae 1878, 90, s. 336: Tertio vero anno Iustini minoris imperatoris Narsis patricius de Ravenna evocitatus, egressus est cum divitiis omnibus Italiae.

14 Vide: D. Mauskopf Deilyannis, Introduction, [w:] Agnellus of Ravenna, The Book of Pontifs of the Church of Ravenna, intro. and transl. D. Mauskopf Deliyannis, Washington D.C. 2004, s. 46-65. 
Bardzo wczesnym źródłem, które łączy Narsesa z longobardzką inwazją jest natomiast Kronika Hydacjusza, a ściśle późniejsza interpolacja dołączona do niej. Jej ostatni passus dotyczy pokonania Wandalów w Afryce i Gotów w Italii przez wodzów Justyniana i kończy się stwierdzeniem, że w późniejszym okresie Narses wydał Italię Alboinowi, królowi Longobardów ${ }^{15}$. Nie wiadomo skąd autor uzupełnienia zaczerpnął te informacje.

O zaproszeniu Longobardów do Italii przez Narsesa pisał w swojej stworzonej ok. 615 r. Chronica maiora także inny autor hiszpański - Izydor z Sewilli. Jako powód podaje on nieokreślone niesnaski, jakie były udziałem wodza i żony cesarza - Zofii ${ }^{16}$. Wersję zdarzeń przedstawioną przez Izydora wkomponował w swoje dzieło także anonimowy autor tzw. Auctarium Havniense, czyli kontynuacji Kroniki Prospera z Akwitanii ${ }^{17}$.

Być może powiązaną z przekazem Izydora tradycję reprezentuje, w swojej stworzonej w połowie VII w. Kronice, frankijski autor Fredegar, który co prawda również uzasadnia sprowadzenie Longobardów przez bizantyńskiego wodza enigmatycznym konfliktem z cesarzową, ale dodatkowo przedstawia przy tym malowniczą anegdotę o złotym wrzecionie, które Zofia miała wysłać będącemu przecież eunuchem Narsesowi, by upokorzyć go i pokazać, że nie nadaje się on do rządzenia, a co najwyżej do pilnowania dziewcząt $\mathrm{w}$ gyneceum ${ }^{18}$. Inspirację dla tej opowieści kronikarz zaczerpnął najprawdopodobniej z paszkwilu stworzonego przez poetę Klaudiusza

${ }^{15}$ Hydatii Lemici Continuatio chronicorum Hieronymianorum, [w:] Monumenta Germaniae Historica, Auctoresantiquissimi (11), Chronica minora saec. IV. V. VI. VII. (II), red. T. Mommsen, Berolini 1894, Continuatio epitomae Hispaniae, s. 36: Narseus [...] qui postremo tempore vitae suae ipsamprovinciam Italiam Alboinoregi Longobardorum tradidit.

${ }^{16}$ Isidoris Iuniorisepiscopi Hispalensis chronica maiora, [w:] Monumenta Germaniae Historica, Auctoresantiquissimi (11), Chronica minora saec. IV. V. VI. VII. (II), red. T. Mommsen, Berolini 1894, 402, s. 476: Narsispatricius [...] Sofiae Augustae Iustiniconiugis minis perterritus Langobardos a Pannoniisinvitavit.

${ }_{17}$ Aucatrii Havniensis Extrema, [w:] Monumenta Germaniae Historica, Auctoresantiquissimi (9), Chronica minora saec. IV. V. VI. VII. (I), red. T. Mommsen, Berolini 1892, 4, s. 337: Narses patricius [...] Sophiae Augustae Iustini coniugis minis motus et obprobriis ignavae feminae perturbatus Alboaenum regem Longobardorum cum omni exercitu suo ab Pannoniis invitavit; $\mathrm{Na}$ temat powiązania tego źródła z dziełem Izydora z Sewilli vide: A Companion to Late Antique Literature, red. S. McGill, E.J. Watts, bmw 2018, s. 181.

${ }^{18}$ Chronicarum quae dicuntur Fredegarii Scholastici libri IV.cum Continuationibus, [w:] Monumenta Germaniae Historica, Scriptores rerum Merovingicarum (2), Fredegarii et aliorum Chronica. Vitae sanctorum, red. B. Krusch, Hannoverae 1888, III 65, s. 110: [...] Narsis patricius minas Iustini impr. Eiusque agustae Sopiae perterritus, eo quod agusta ei adparatum ex auro facto muliebri, eo quod eonucu serat, cum quo filaret, direxit; et pensilariis regerit non populo. At ille respondens: Filo filabo, de quem Iustinus imperator nec agusta ad caput venire non possit. Tunc Langobardus a Pannoniis invitans, cum Albueno regi Aetaliam introduxit. 
Klaudiana i wymierzonego w innego odgrywającego istotną rolę w historii cesarstwa eunucha - Eutropiusza. W dziele tym występują bowiem bardzo podobne inwektywy ${ }^{19}$.

Narsesa i Longobardów łączy także narracja anonimowego biogramu papieża Jana III, znajdująca się w kompilacji biogramów biskupów Rzymu znanej jako Liber pontificalis. Biografia Jana powstała najprawdopodobniej w latach 30. VII w., stanowi więc źródło stosunkowo wczesne. Stworzone zostało w kręgu kurii rzymskiej, niewątpliwie bardzo dobrze zorientowanej w sytuacji bizantyńskiej Italii, więc jego narracji nie należy lekceważyć, szczególnie, że stanowi ona zdecydowanie najobszerniejszy oryginalny przekaz dotyczący okoliczności upadku Narsesa ${ }^{20}$. Wedle tej wersji wódz poczuł się bardzo urażony dotyczącymi go skargami kierowanymi do Justyna i Zofii przez ludność rzymską, która obwiniała go o zbytni ucisk. Miał wtedy opuścić Rzym, udać się do Kampanii i stamtąd wysłać do Longobardów pismo, zachęcając ich do zajęcia Italii ${ }^{21}$.

Krótka wzmianka o zaproszeniu Longobardów do Italii (bez wątku konfliktu z Zofią lub lokalną ludnością) znalazła się także w będącym najpewniej odzwierciedleniem tradycji longobardzkiej anonimowym źródle z końca VII w., znanym jako Origo gentis Langobardorum ${ }^{22}$.

Obszerny fragment dotyczący Narsesa i jego związków z Longobardami, znajdujący się w stworzonej pod koniec VIII w. (więc późno) Historii Longobardów Pawła Diakona pozbawiony jest elementów autorskich i stanowi dosłowną kompilację informacji zaczerpniętych z Liber pontificalis i Kroniki Fredegara, uzupełnionych krótką wzmianką (zaczerpniętą być może z Excerpta Sangallensia) o pojawieniu się w Italii prefekta Longinusa, wysłanego tam w miejsce Narsesa ${ }^{23}$. Przekaz Pawła Diakona został następnie

19 Vide: L. Fauber, Narses..., s. 179-180.

${ }^{20} \mathrm{Na}$ temat charakterystyki źródła vide: T.F.X. Noble, Literacy and the papal government in late antiquity and the early middle ages, [w:] The Uses of Literacy in Early Mediaeval Europe, red. R. McKitterick, Cambridge 1990, s. 96-98.

${ }^{21}$ Liber Pontificalis I-XCVI (usque ad annum 772) [Księga Pontyfików 1-96 (do roku 772)], tekst polski i łaciński, tłum. P. Szewczyk, M. Jesiotr, Kraków 2014, LXIV 3-5, s. 167.

22 Origo, 5, s. 4: Albuin adduxit Langobardos in Italia, invitatos a Narsete scribarum.

${ }^{23}$ Paweł Diakon, II, 5, s. 75; Jedynym oryginalnym elementem w narracji Pawła Diakona jest opowieść o italskich owocach i innych dobrach, które miał na zachętę wysłać Longobardom Narses. Epizodu tego nie należy jednak traktować jako świadectwa korzystania przez autora z jakiejś odrębnej tradycji, a jedynie jako jeden z jego literackich wymysłów. Zabieg ten miał na celu ubarwić opowieść (Paweł Diakon dość często uciekał się do podobnych rozwiązań) i zdradza ewidentną inspirację starotestamentową historią o zwiadowcach wysyłanych przez Mojżesza, którzy mieli przynieść Izraelitom owoce z Ziemi Obiecanej vide: S.M. Cingolani, Le storie dei Longobardi. Dall'origine a Paolo Diacono, Roma 1995, s. 134. 
streszczony w IX w. w dwóch innych italskich źródłach - Kronice Andrzeja z Bergamo ${ }^{24}$ czy tzw. Chronica Sancti Benedicti Casinensis ${ }^{25}$. Teoretycznie można założyć, że autorzy tych dzieł, wszyscy żyjący przecież w Italii, choć kopiowali dosłownie inne przekazy, robili to dlatego, że pokrywały się z jakąś ogólną, znaną im tradycją lokalną. Bardziej prawdopodobne jest jednak, że po upływie tak długiego czasu od opisywanych wydarzeń, pamięć o nich była już mglista i autorzy opierali się wyłącznie na kopiowanych przez siebie źródłach, nie konfrontując ich z żadną inną tradycją (czy to ustną czy pisaną), która mogłaby potwierdzać ich przekaz. W tej sytuacji wszystkie trzy przekazy należy traktować jako cechujące się bardzo ograniczoną przydatnością, drugo lub nawet trzeciorzędną na tle źródeł omawianych wcześniej.

Zupełnie bezwartościowa jest z kolei narracja Bedy Czcigodnego, który w swojej Chronica maiora (I poł. VIII w.), pisząc o Narsesie, opierał się wyłącznie na Liber pontificalis oraz dziele Izydora z Sewilli ${ }^{26}$. Wątpliwe, by pochodzący z Brytanii autor (siłą rzeczy niezanurzony więc w italskiej rzeczywistości) mógł zdobyć rozeznanie na temat spraw półwyspu, rozgrywających się w tak odległych czasach, jakąś inną drogą, niż na podstawie czytanych przez siebie źródeł. Należy więc uznać go jedynie za kompilatora znanych skądinąd informacji.

Interesującym przekazem dotyczącym ewentualnych kontaktów Narsesa z Longobardami jest natomiast inne późne źródło - anonimowa Historia Langobardorum codicis gothani z początku IX w. Jego autor wzorował swoje krótkie dzieło niewątpliwie na Origo, korzystając także z Historii Longobardów. Fragment, w którym pisze o zaproszeniu Longobardów do Italii przez Narsesa, wykazuje jednak zadziwiające podobieństwo leksykalne do przekazów Izydora i Auctarium Havniense. Ponadto zawiera także nieznaną skądinąd wzmiankę o rzekomym udaniu się Narsesa do Hiszpanii, tuż po oddaniu Longobardom Italii ${ }^{27}$. Sugerować to może, że znał on też jakąś odrębną, nieznaną z innych źródeł tradycję o tych wydarzeniach.

${ }^{24}$ Andreae Bergomatis historia, [w:] Monumenta Germaniae Historica, Scriptores rerum Langobardicarum et Italicarum, red. G. Waitz, Hannoverae 1878, s. 222.

${ }^{25}$ Chronica Sancti Benedicti Casinensis, [w:] Monumenta Germaniae Historica, Scriptores rerum Langobardicarum et Italicarum, red. G. Waitz, Hannoverae 1878, 2, s. 468.

${ }^{26}$ Chronicon, sive de sex hujus seculi aetatibus, [w:] Bede opera historica minora, red. J. Stevenson, Londini 1841, 4529, s. 192.

${ }^{27}$ Codicis gothani, 5, s. 9: Iste albuin movit et adduxit langobardos in italia, invitatus ad nearside proconsule et praeside italiae, qui minas suffiae reginae erat perterritus. [...] Nam narsis proconsul italiae, si quid eorum promiserat, relinquens italiam, ad spaniarum provinciam est reversus. 


\section{Narses a inwazja longobardzka na Italię w $568 \mathrm{r}$. Przegląd opinii historiograficznych}

Duże rozbieżności przekazów źródłowych dotyczących związków (bądź ich braku) Narsesa z wkroczeniem Longobardów do Italii, spowodowały, że wśród badaczy, poruszających na przestrzeni lat to zagadnienie, występowały zauważalne różnice zdań.

Przypadki pełnej afirmacji wersji wydarzeń przedstawianej m. in. przez Liber pontificalis są rzadkie. Jako najbardziej znaczący przykład można podać klasyczne dzieło Edwarda Gibbona, który wychodził z założenia, że opowieść ta jest jak najbardziej wiarygodna, a Longobardowie, nie mając poparcia Narsesa, nie mieliby dużych szans zawojowania Italiii ${ }^{28}$.

Dość popularne jest stanowisko polegające na negacji wiarygodności opowieści o zaproszeniu wystosowanym przez Narsesa i uznaniu, że wódz nie miał nic wspólnego z inwazją. Zwolennikiem takiego poglądu był chociażby autor znanej syntezy dziejów Italii wczesnośredniowiecznej - Thomas Hodgkin. Według niego kluczowym argumentem był fakt, że Narsesa i Longobardów nie łączą najwcześniejsze źródła. Przeciwko wiarygodności przekazów późniejszych miałyby przemawiać obecne w nich dość absurdalne informacje drugoplanowe, jak np. rzekoma podróż Narsesa do Kampanii, by stamtąd nawiązać kontakt z Longobardami (z punktu widzenia logiki powinien udać, się w kierunku, z którego mogliby nadejść Longobardowie - czyli na północ) ${ }^{29}$. Jörg Jarnut uznał, że autorzy późniejszych źródeł łączyli ze sobą Narsesa i Longobardów po prostu ze względu na koincydencję czasową tych dwóch zdarzeń i słabość bizantyńskiego oporu, którą próbowano wytłumaczyć zdradą ${ }^{30}$. Najwcześniejsze źródła zostały ocenione jako najbardziej wiarygodne także przez Lawrence Fauberta. W jego opinii przeciwko konszachtom wodza z Longobardami i konfliktowi z parą cesarską, przemawiają dodatkowo obecne w źródłach informacje, że po śmierci ciało Narsesa odesłano do Konstantynopola, a Justyn II i Zofia byli obecni w trakcie pochówku ${ }^{31}$. Na polskim gruncie zwolenniczką tezy o braku współpracy między Narsesem a Longobardami w latach 60. VI w. jest Teresa Wolińska. Łódzka historyk podkreśla, że narracja o zdradzie przeważnie obecna jest w źródłach bardzo późnych. Do wypaczenia opowieści o schyłkowym etapie kariery Narsesa doprowadzić miała zbieżność odwołania wodza z Italii

${ }^{28}$ E. Gibbon, The Decline and Fall of the Roman Empire, vol. 2, red. J.B. Bury, New York 1995, s. 692-693.

${ }^{29}$ T. Hodgkin, Italy and her Invaders, vol. 5, b. 6, red. 2, Oxford 1916, s. 59-67.

30 J. Jarnut, Storia dei Longobardi, tłum. P. Guglielmotti, Torino 1995, s. 31.

${ }^{31}$ L. Fauber, Narses..., s. 176-185. 
z najazdem i jednoczesna pamięć o jego kontaktach z Longobardami z lat 50. VI w. ${ }^{32}$ Przekazy źródeł łączących wodza z najeźdźcami określił jako naiwne Jerzy Strzelczyk ${ }^{33}$. Opowieść o współpracy z Longobardami w 568 r. za mało wiarygodną uznał także Michael Stewart ${ }^{34}$.

Część historyków, nie mogąc zdecydować się czy bardziej należy wierzyć grupie najwcześniejszych źródeł nie zawierających informacji o ewentualnych kontaktach czy dość licznemu mimo wszystko korpusowi niezależnych od siebie przekazów takie informacje zawierających, zabiera ostrożne stanowisko. Iwan Dujczew powstrzymywał się przed deprecjonowaniem narracji o zdradzie, z drugiej jednak strony stwierdzał, że stanowiła ona idealne propagandowe usprawiedliwienie dla longobardzkiej bytności w Italii, a odwołanie wodza mogło być czynnikiem, który zachęcił barbarzyńców do marszu w kierunku słabo bronionego półwyspu ${ }^{35}$. 0 możliwości wystosowania z obszaru bizantyńskiej Italii (nie wymieniając przy tym imienia Narsesa) jakiegoś sekretnego zaproszenia w kierunku Longobardów pisał Paolo Delogu, nie rozwijając jednak wątku ${ }^{36}$. Od wydania konkretnego sądu powstrzymał się Giorgio Ravegnani, ograniczając się do konkluzji, że w przekazach dotyczących konfliktu z władzą cesarską i zaproszenia Longobardów, prawda łączy się z elementami legendarnymi i raczej niemożliwe jest oddzielenie ich od siebie ${ }^{37}$. Przed zajęciem jasnego stanowiska wstrzymał się także Walter Pohl ${ }^{38}$. Duży sceptycyzm wobec ewentualnego zaproszenia Longobardów przez Narsesa zachował Stefano Gasparri, nie twierdząc jednak kategorycznie, że taka wersja wydarzeń była całkowicie niemożliwa, zważywszy na konflikt między wodzem a parą cesarską ${ }^{39}$. Z kolei tacy badacze jak Stefano Maria Cingolani i Francesco Borri, analizując przekaz źródeł dotyczący ewentualnych konszachtów Narsesa z Longobardami, zrezygno-

32 T. Wolińska, Armeńscy współpracownicy..., s. 44-46.

${ }_{33}$ J. Strzelczyk, Longobardowie. Ostatni z wielkiej wędrówki ludów, Warszawa 2014, s. 42-43.

34 M.E. Stewart, The Andreios Eunuch - Commander Narses: Sign of a Decoupling of Martial Virtues and Masculinity in the Early Byzantine Empire?, „Ceræ: An Australasian Journal of Medieval and Early Modern Studies" 2015, no. 2, s. 17.

35 I. Dujcev, Bizantini e Longobardi, [w:] Atti del Convegno Internazionale sul tema. La civiltà dei Longobardi in Europa. Roma, 24-26 maggio 1971; Cividale del Friuli, 27-28 maggio 1971, Roma 1974, s. 58-60.

${ }^{36}$ P. Delogu, Il regno Longobardo, [w:] Longobardi e Bizantini, red. G. Galasso, Torino 1980, s. 13.

37 G. Ravegnani, I Bizantini in Italia, Bologna 2004, s. 69-71.

${ }^{38}$ W. Pohl, The Empire and the Lombards..., s. 98-99.

39 S. Gasparri, Italia longobarda. Il regno, I Franchi, il papato, Bari 2016, s. 13. Nie wiedzieć czemu, pisząc o sporach Narsesa z cesarską parą, S. Gasparri wymienił Justyniana i Teodorę, a nie Justyna II i Zofię. 
wali z wyraźnych prób rozstrzygania kwestii ich historyczności, skupiając się na literackim i retorycznym aspekcie narracji ${ }^{40}$.

Autorem bardzo ciekawej koncepcji, próbującej pogodzić sprzeczną narracjęźródeł jest Neil Christie. Według brytyjskiego historyka, Longobardowie zostali rzeczywiście zaproszeni do Italii, ale za aprobatą władz w Konstantynopolu (Christie wyklucza istnienie konfliktu między Narsesem a parą cesarską). Spowodowane było to brakiem rekruta i koniecznością obrony granic, w czym mogło pomóc osadzenie w Longobardów w północnej Italii jako sojuszników cesarstwa. Ich wkroczenie dopiero potem przerodziło się w niekontrolowaną inwazję. Plotki o zdradzie Narsesa miały być natomiast efektem niechęci, jaką żywiły do niego elity italskie, rozczarowane jego polityką fiskalną oraz zbieżności inwazji z momentem odwołania go ${ }^{41}$.

\section{Próba reinterpretacji}

Brak informacji na temat związku longobardzkiej inwazji z odwołaniem Narsesa w najwcześniejszych (powstałych w ostatnim 25-leciu VI w.) źródłach zachodnich i całkowite milczenie na ten temat autorów bizantyńskich są bardzo wymowne, jakkolwiek przyjmowanie ich jako bezwarunkowego dowodu na niesłuszność późniejszych oskarżeń musi budzić pewne zastrzeżenia. Teoretycznie można bowiem założyć, że przyczyną milczenia źródeł greckojęzycznych i powstałych na terytorium bizantyńskiej Italii Excerpta Sangallensia jest chęć ukrycia poczynań wodza, niezbyt chlubnych w kontekście jego dawnych zasług i prestiżu państwa. Grzegorz z Tours z kolei zamieścił wzmiankę o Narsesie jedynie jako dygresję we fragmencie dotyczącym cesarza Tyberiusza i nie miał powodu, by rozwodzić się w tym miejscu nad jego konszachtami z Longobardami. Pozwala to postawić hipotezę, że milczenie autora na ten temat niekoniecznie musi oznaczać, że w jego przekonaniu wódz nie miał nic wspólnego z longobardzkim najazdem. Z drugiej strony tego rodzaju rozważania mają charakter mocno uznaniowy i kwestionują je dość trudne do podważenia relacje Mariusza z Avenches i (w mniejszym stopniu) Jana z Biklar.

Arbitralne odrzucanie wszystkich przekazów, wedle których Narses współpracował z Longobardami, nie wydaje się jednak dobrym rozwiązaniem. Jeden z nich, interpolacja z Kroniki Hydacjusza, jest zresztą

40 F. Borri, Alboino. Frammenti di un racconto (secoli VI-IX), Roma 2016, s. 43-46; S.M. Cingolani, Le storie dei Longobardi..., s. 134.

${ }^{41} \mathrm{~N}$. Christie, Invasion or invitation? The Longobard occupation of northern Italy, A.D. 568-569, „Romanobarbarica” 1991, vol. 11, s. 102-107. 
najprawdopodobniej równie wczesny jak źródła niewiążące wodza z inwazją. Izydor z Sewilii (piszący później, ale mimo wszystko stosunkowo wcześnie, bo ok. 615 r.), być może korzystający z tego źródła, korzystał też na pewno z jakiegoś innego kanału informacji, ponieważ jako pierwszy wplótł w narrację o tych wydarzeniach wzmiankę o jakimś nieokreślonym konflikcie wodza z cesarzową. Niezależny przekaz stanowi także wersja wydarzeń podana w rzymskim Liber pontificalis, prawdopodobnie w latach 30. VII w. Cenny jest także stanowiący odzwierciedlenie ustnej tradycji longobardzkiej fragment Origo gentis Langobardorum, choć źródło to jest dość późne. Śladu niezależnego kanału informacji dotyczących tych wydarzeń można się też doszukać w narracji Historia Langobardorum codicis gothani.

Ewentualną zdradę Narsesa poświadcza więc kilka niezależnych (bądź zależnych częściowo) od siebie przekazów. Jeden z nich należy uznać za bardzo wczesny, dwa zaś za dość wczesne. Czynniki te nie pozwalają więc przejść koło nich obojętnie. Tłumaczenia, że stosunek Liber pontificalis do Narsesa jest jedynie odzwierciedleniem niechęci do jego praktyk jako administratora, a źródła longobardzkie wiążą go z inwazją, jedynie by zalegitymizować pobyt Longobardów w Italii, nie wydają się wystarczające. Podobny cel propagandowy trudno wskazać bowiem w przypadku wcześniejszych od nich źródeł iberyjskich.

W tej sytuacji, najrozsądniejszą postawą badawczą jest zachowanie ostrożności przy jednoznacznej ocenie wartości narracji przedstawianej przez poszczególne źródła, ponieważ trudno udowodnić całkowitą fałszywość którejkolwiek z nich. Przekonywującą alternatywę mogą stanowić próby godzenia przekazów źródłowych, w rodzaju tej podjętej przez Neila Christiego. Interpretacja zaproponowana przez brytyjskiego historyka ma jednak zasadniczy mankament, który wskazał Walter Pohl. Cesarz Justyn II, wstępując na tron, porzucił politykę Justyniana Wielkiego, polegającą na utrzymywaniu równowagi między Bizancjum a ludami barbarzyńskimi (pomijając oczywiście Ostrogotów i Wandalów) poprzez wiązanie ich $\mathrm{z}$ cesarstwem siecią sojuszy i tolerowaniu ich pobytu nawet $\mathrm{w}$ granicach imperium. Nowy władca szybko zaprzestał wypłacania trybutów Awarom i Persom oraz odwrócił się od Longobardów i Gepidów, przychylnie spoglądając na zagładę państwa tych ostatnich i zajmując ważne strategicznie Sirmium. Prowadzący tak silnie konfrontacyjną wobec barbarzyńców politykę cesarz raczej nie mógłby zgodzić się na osiedlenie Longobardów w Italii, by ci bronili jej granic ${ }^{42}$.

${ }^{42}$ W. Pohl, Die Awaren. Ein Steppenvolk in Mitteleuropa 567-822 n. Chr., München 1988, s. 48-54; idem, The Empire and the Lombards..., s. 98-99. 
Uwagi Pohla wcale nie muszą jednak podawać w wątpliwość całości interpretacji Christiego, jeśli wprowadzić do niej pewne poprawki. Narses mógł przecież osiedlić Longobardów w Italii działając w dobrej wierze, ale wbrew woli Justyna i Zofii, których jego postepowanie musiało wprowadzić w gniew. Tłumaczyłoby to zbieżność inwazji i odwołania wodza z pełnionych funkcji oraz obecność w źródłach informacji dotyczących konfliktu z posiadającą duży wpływ na męża Zofią. Należy jednak pamiętać, że Longobardowie mieli wystarczająco dużo powodów, by wyruszyć do Italii, nie czekając na żadne zachęty ze strony miejscowej administracji. Panonia nie była bowiem zbyt zasobna na tle Italii, nawet nadszarpniętej mocno wojnami gockimi. Król Alboin już od początku panowania mógł myśleć o migracji, na co mogą wskazywać poszlaki w postaci ewidentnego dążenia władcy do zgromadzenia pod swoim przywództwem jak najliczniejszego konglomeratu ludów, być może po to, by skutecznie stawić czoła zagrożeniom, z którymi trzeba było się liczyć w nowym miejscu. Nawet jeśli tak nie było, to inny impuls mogło stanowić zbytnie umocnienie się Awarów po upadku państwowości gepidzkiej, które groziło Longobardom popadnięciem w zależność od nich. Alboin miał też pewnie świadomość, że Italia jest stosunkowo słabo broniona, co czyniło potencjalny podbój realnym ${ }^{43}$. W tej sytuacji całkiem możliwe, że Longobardowie rozpoczęli wędrówkę niezapraszani przez Narsesa. Wódz, postawiony wobec faktów dokonanych, kiedy ci znaleźli się już po drugiej stronie Alp, zdecydował natomiast, że musi podjąć przynajmniej jakieś prowizoryczne środki zaradcze. Próbował więc być może (mimo świadomości, że trudno będzie liczyć na pełną lojalność Longobardów, czego ci dowiedli podczas ekscesów, których dopuścili się walcząc pod jego komendą w latach 50.) zalegalizować pobyt najeźdźców w północnej Italii i osiedlić ich tam jako bizantyńskich foederati. Takie zabiegi poskutkowały odwołaniem go przez niechętnych tego rodzaju polityce Justyna i Zofię, a Longobardowie, już zupełnie niekontrolowani, zaczęli przemieszczać się w głąb półwyspu.

Tego rodzaju propozycja jest jedynie hipotezą i nie należy jej w żadnym wypadku traktować jako wykluczającej inne stanowiska. Rozbieżności między treścią źródeł i jednoczesna trudność w bezsprzecznym kwestionowaniu występujących w nich wersji wydarzeń (niezależnie, czy wiążących Narsesa z Longobardami czy nie) sprawiają bowiem, że niemożliwe jest stworzenie jednej interpretacji, która mogłaby wyprzeć inne. Łatwiejszą do powszechnego zaakceptowania może natomiast wydać się propozycja, by z dyskusji nad związkami Narsesa i Longobardów wykluczyć lub

${ }^{43} \mathrm{Na}$ temat motywacji, które mogły spowodować migrację vide: N. Christie, Invasion or invitation..., s. 98-102; J. Jarnut, Storia dei Longobardi, s. 29-31; W. Pohl, Die Awaren..., s. 54-58. 
przynajmniej zepchnąć na odległy plan niektóre źródła ewidentnie kopiujące inne przekazy. Chodzi tutaj o bardzo późne źródła Italskie (Historia Longobardów Pawła Diakona, Historia Andrzeja z Bergamo czy Chronica Sancti Benedicti Casinensis) oraz przynajmniej część przekazów zależnych od Chronica maiora Izydora z Sewilli. Szczególnie rzucający się w oczy przypadek stanowi wykorzystywanie dzieła Pawła Diakona. Choć bardzo odległe w czasie od opisywanych wydarzeń i stanowiące dosłowną kompilację innych przekazów, jest często przywoływane przez badających zagadnienie historyków jako jedno z kluczowych źróde ${ }^{44}$.

\section{BIBLIOGRAFIA}

\section{Źródła}

Agnelli liber pontificalis ecclesiae Ravennatis, [w:] Monumenta Germaniae Historica, Scriptores rerum Langobardicarum et Italicarum, ed. G. Waitz, Hannoverae 1878.

Andreae Bergomatishistoria, [w:] Monumenta Germaniae Historica, Scriptores rerum Langobardicarum et Italicarum, ed. G. Waitz, Hannoverae 1878.

Aucatrii Havniensis Extrema, [w:] Monumenta Germaniae Historica, Auctoresantiquissimi (9), Chronica minora saec. IV. V. VI. VII. (I), ed. T. Mommsen, Berolini 1892.

Chronica Sancti Benedicti Casinensis, [w:] Monumenta Germaniae Historica, Scriptores rerum Langobardicarum et Italicarum, ed. G. Waitz, Hannoverae 1878, 2, s. 468.

Chronicarum quae dicuntur Fredegarii Scholastici libri IV. cum Continuationibus, [w:] Monumenta Germaniae Historica, Scriptores rerum Merovingicarum (2), Fredegarii et aliorum Chronica. Vitae sanctorum, ed. B. Krusch, Hannoverae 1888.

Chronicon, sive de sex hujus seculi aetatibus, [w:] Bede opera historica minora, ed. J. Stevenson, Londini 1841.

Excerpta Sangallensia, [w:] Monumenta Germaniae Historica, Auctoresantiquissimi (9), Chronica minora saec. IV. V. VI. VII. (I), ed. T. Mommsen, Berolini 1892.

Gregorii episcopi Turonensis libri historiarum X, [w:] Monumenta Germaniae Historica, Scriptores rerum Merovingicarum (1,1), Gregorii Turonensis Opera. Teil 1: Libri historiarum X, ed. B. Krusch, W. Levison, Hannoverae 1951.

Historia Langobardorum codicis Gothani, [w:] Monumenta Germaniae Historica, Scriptores rerum Langobardicarum et Italicarum, ed. G. Waitz, Hannoverae 1878.

The History of Menander the Guardsman, intro. and transl. R.C. Blockley, Liverpool 1985.

The History of Theophylact Simocatta, intro. and transl. Michael and Mary Whitby, Oxford 1986.

${ }^{44}$ Vide: np. I. Dujcev, Bizantini e Longobardi, s. 58-60; G. Ravegnani, I Bizantini in Italia, s. 69-71; W. Pohl, The Empire and the Lombards..., s. 98-99. 
Hydatii Lemici Continuatio chronicorum Hieronymianorum, [w:] Monumenta Germaniae Historica, Auctoresantiquissimi (11), Chronica minora saec. IV. V. VI. VII. (II), ed. T. Mommsen, Berolini 1894.

Iohannis Abbatis Biclarensis Chronica, [w:] Monumenta Germaniae Historica, Auctoresantiquissimi (11), Chronica minora saec. IV. V. VI. VII. (II), ed. T. Mommsen, Berolini 1894, s. 213-219.

Isidoris Iunioris episcopi Hispalensis chronica maiora, [w:] Monumenta Germaniae Historica, Auctoresantiquissimi (11), Chronica minora saec. IV. V. VI. VII. (II), ed. T. Mommsen, Berolini 1894.

Liber Pontificalis I-XCVI (usque ad annum 772) [Księga Pontyfików 1-96 (do roku 772)], tekst polski i łaciński, tłum. P. Szewczyk, M. Jesiotr, Kraków 2014.

Marii episcopi Aventicensischronica, [w:] Monumenta Germaniae Historica, Auctoresantiquissimi (11), Chronica minora saec. IV. V. VI. VII. (II), ed. T. Mommsen, Berolini 1894.

Origogentis Langobardorum, [w:] Monumenta Germaniae Historica, Scriptores rerum Langobardicarum et Italicarum, ed. G. Waitz, Hannoverae 1878.

Pauli historia Langobardorum, [w:] Monumenta Germaniae Historica, Scriptores rerum Langobardicarum et Italicarum, ed. G. Waitz, Hannoverae 1878.

Prokopiusz z Cezarei, Historia Wojen. Tom II - Wojny z Gotami [dalej: Prokopiusz z Cezarei], wstęp i tłum. D. Brodka, Kraków 2015.

\section{Opracowania}

A Companion to Late Antique Literature, ed. S. McGill, E.J. Watts, bmw 2018.

Borri F., Alboino. Frammenti di un racconto (secoli VI-IX), Roma 2016.

Cesaretti P., I Longobardi di Procopio, [w:] I Longobardi e la storia. Un percorsoattraverso le fonti, red. F. Lo Monaco e F. Mores, Roma 2012.

Christie N., Invasion or invitation? The Longobard occupation of northern Italy, A.D. 568-569, „Romanobarbarica” 1991, vol. 11.

Christie N., The Lombards. The Ancient Longobards, Oxford 1995.

Cingolani S.M., Le storie dei Longobardi. Dall'origine a Paolo Diacono, Roma 1995.

Delogu P., Il regno Longobardo, [w:] Longobardi e Bizantini, red. G. Galasso, Torino 1980.

Dujcev I., Bizantini e Longobardi, [w:] Atti del Convegno Internazionale sul tema. La civiltà dei Longobardi in Europa. Roma, 24-26 maggio 1971; Cividale del Friuli, 27-28 maggio 1971, Roma 1974.

Fauber L., Narses. Hammer of the Goths, Gloucester-New York 1990.

Gasparri S., Italia longobarda. Il regno, I Franchi, il papato, Bari 2016.

Gibbon E., The Decline and Fall of the Roman Empire, vol. 2, ed. J.B. Bury, New York 1995.

Hodgkin T., Italy and her Invaders, vol. 5, b. 6, ed. 2, Oxford 1916.

Jarnut J., Storia dei Longobardi, tłum. P. Guglielmotti, Torino 1995.

Kaldellis A., Classicism, Barbarism, and Warfare: Prokopios and the Conservative Reaction to Later Roman Military Policy, „American Journal of Ancient History” 2004-2005, no. 3-4.

Lamma P., Sulla fortuna dei longobardi nel la storiografia bizantina, [w:] Atti del primo Congresso Internazionale di Studi Longobardi: Spoleto, 27.-30 sett. 1951, Spoleto 1952. 
Mauskopf Deilyannis D., Introduction, [w:] Agnellus of Ravenna, The Book of Pontifs of the Church of Ravenna, intro. and transl. D. Mauskopf Deliyannis, Washington D.C. 2004.

Noble T.F.X., Literacy and the papal government in late antiquity and the early middle ages, [w:] The Uses of Literacy in Early Mediaeval Europe, ed. R. McKitterick, Cambridge 1990.

Pohl W., Die Awaren. Ein Steppenvolk in Mitteleuropa 567-822 n. Chr., München 1988.

Pohl W., The Empire and the Lombards: Treaties and Negotiations in the Sixth Century, [w:] Kingdoms of the Empire: The Integration of Barbarians in Late Antiquity, ed. W. Pohl, Leiden 1997.

Ravegnani G., I Bizantini in Italia, Bologna 2004.

Sarantis A., War and Diplomacy in Pannonia and the Northwest Balkans during the Reign of Justinian: The Gepid Threat and Imperial Responses, „Dumbarton Oaks Papers” 2009, vol. 63.

Stewart M.E., The Andreios Eunuch - Commander Narses: Sign of a Decoupling of Martial Virtues and Masculinity in the Early Byzantine Empire?, „Ceræ: An Australasian Journal of Medieval and Early Modern Studies" 2015, no. 2.

Strzelczyk J., Longobardowie. Ostatni z wielkiej wędrówki ludów, Warszawa 2014.

Wolińska T., Armeńscy współpracownicy Justyniana Wielkiego. Część 2. Wielka kariera eunucha Narsesa, „Przegląd Nauk Historycznych” 2005, R. 4, nr 1.

Wozniak F.E., Byzantine Diplomacy and the Lombard-Gepidic Wars, „Balkan Studies” 1979, vol. 20.

Maciej Dawczyk

\section{NARSES AND THE LOMBARDS}

First contact between Narses and Lombards took place probably during the campaign

Fagainist Ostrogoths in 552 when Lombardsfought under his command. They seemed to be brave soldiers but simultaneously became authors of many assaults on local people and were sent back to their native Pannonia. According to some sources (e.g. Isidore of Sevilla, Liber pontificalis) Narses invited Lombards to Italy in 568 because he wanted to take his revenge on empress Sophia. This version however is not confirmed by the majority of earliest sources (e.g. Marius of Avenches, Gregory of Tours, all byzantine sources). Nonetheless the narration about collaboration between the byzantine commander and Lombards should not be all rejected because it is present in many independent and quite reliable sources. In connection to the hypothesis created by Neil Christie there is possibility to propose its extension which could unite contradict narrations. This extension could solve the problem which is contradiction between hypothetical deliberate settling of Lombards and contemporary policy of empire under Justin II which was very unfavorable for barbarians. It is possible that Narses contacted with Lombards in good faith, but did it against the will of imperial pair. The result was his removal. It is possible too that the attempt to settle Lombards was not the effect of the invitation but only failed attempt of fixing the situation caused by their lawless arrival.

Keywords: Byzantium, Italy, Lombards, Middle Ages, Narses. 